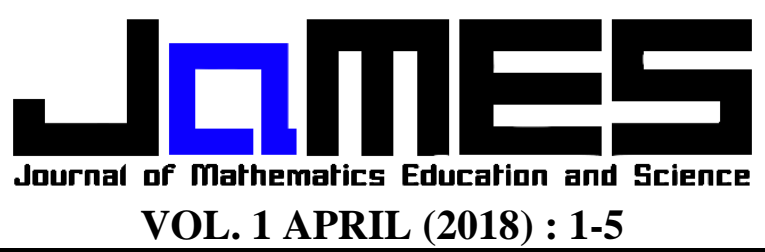

\title{
ANALISIS KOMUNIKASI MATEMATIS SISWA DALAM MEMECAHKAN MASALAH MATEMATIKA BERDASARKAN GAYA KOGNITIF REFLECTIVE-IMPULSIVE KELAS VII SMP NEGERI 1 SUMBERREJO
}

\author{
Anisa Fitri ${ }^{1}$ \\ Universitas Nahdlatul Ulama Sunan Giri, anisafitri@ unugiri.ac.id ${ }^{1}$ \\ Received : 20 Maret 2018, Accepted : 1 April 2018, @ Mathematics Education Unugiri 2018
}

\begin{abstract}
This research aims to analyze the ability of mathematical communicationin problem solving who had reflective cognitive style's, and impulsive cognitive style's in the first grade of SMP Negeri 1 Sumberrejo on mathematical written, drawing mathematically, and mathematical expression aspect's. The research is a qualitative research with subjects in this research were eight students of class VII C SMP Negeri 1 Sumberrejo which consisting of four students with reflective cognitive style's, four student with impulsive cognitive style's. The subject in this research were taken by using purposive sampling technique. Data was collected by the results of written tests and interviews. Data analysis techniques used data reduction, data presentation, and conclusion. The validity of the data usetime triangulation that compared data of the first task and interview with the second task and interview. The results showed that: (1) students with reflective cognitive styles: the mathematical written ability are on the fourth level, drawing mathematically are on the third level, and mathematical expression are on the third level, (2) students with impulsive cognitive styles: the mathematical written ability are on the third level, drawing mathematically are on the second level, and mathematical expression are on the second level.
\end{abstract}

\section{Keywords: Mathematical Communication, Reflective-Impulsive}

\begin{abstract}
Abstrak
Penelitian ini bertujuan untuk mendeskripsikan kemampuan komunikasi matematis siswa dengan kategori gaya kognitif yakni reflective, dan impulsive, kelas VII SMP Negeri 1 Sumberrejo pada aspek menulis matematis, menggambar secara matematis, dan ekspresi matematis. Penelitian ini merupakan penelitian kualitatif dengan subjek penelitian delapan siswa kelas VII C SMP Negeri 1 Sumberrejo yang terdiri dari empat siswa dengan gaya kognitif reflective, empat siswa dengan gaya kognitif impulsive. Penentuan subjek penelitian menggunakan purposive sampling. Teknik pengumpulan data menggunakan tes tertulis dan wawancara. Teknik analisis data yang digunakan meliputi pengumpulan data, reduksi data, penyajian data dan verifikasi.Validitas data yang digunakan dalam penelitian ini menggunakan triangulasi waktu yang membandingkan antara data tertulis dan wawancara I dengan data tertulis dan wawancara II. Hasil penelitian menunjukkan bahwa kemampuan komunikasi matematis untuk siswa gaya kognitif reflective meliputi: kemampuan menulis matematis berada pada tingkat 4 , kemampuan menggambar secara matematis berada pada tingkat 3, dan kemampuan ekspresi matematis berada pada tingkat 3 . Kemampuan komunikasi matematis untuk siswa dengan gaya kognitif impulsive meliputi: kemampuan menulis matematis berada pada tingkat 4, kemampuan menggambar secara matematis berada pada tingkat 2, dan kemampuan ekspresi matematis berada pada tingkat 2 .
\end{abstract}

Kata kunci: Komunikasi matematis, Reflektif-impulsif

\section{Pendahuluan}

Mata pelajaran matematika erat kaitannya dengan simbol-simbol, istilah-istilah, rumus, diagram ataupun tabel, sehingga mata pelajaran matematika juga dapat dipandang sebagai suatu bahasa. Menurut Depdiknas [2], salah satu tujuan 
adanya pelajaran matematika adalah agar peserta didik dapat mengkomunikasikan gagasan untuk memperjelas keadaan atau masalah. Hal tersebut memperjelas bahwa komunikasi matematis merupakan salah satu kemampuan penting yang harus dikembangkan dalam diri siswa. Selain itu, menurut National Council of Teacher of Mathematics (NCTM) [7] komunikasi matematis juga merupakan salah satu dari lima standar kompetensi yang utama dalam pelaksanaan pembelajaran matematika di sekolah, yaitu kemampuan pemecahan masalah (Problem Solving), kemampuan komunikasi (Communication), kemampuan koneksi (Connection), kemampuan penalaran (Reasoning), dan representasi (Representation).

Pentingnya komunikasi matematis juga disampaikan oleh Baroody [3]: There are two important reasons for focusing mathematics teaching on communication, (1) mathematics is essentially a language; mathematics is more than just a tool for thinking, a means of finding patterns, solving problems, or making inferences, rather mathematics is also an invaluable tool for communicating ideas clearly, precisely, and concisely, and (2) mathematics and mathematics learning are, at heart, social activities in mathematics teaching, interactions such as communication between teachers and among student themselves, it is important to enhance the mathematical potential of student. Maksud dari pernyataan tersebut yakni terdapat dua alasan penting untuk memfokuskan mengajar matematika pada komunikasi, (1) matematika pada dasarnya adalah sebuah bahasa, matematika bukan hanya sekedar alat untuk berpikir, untuk menemukan pola, memecahkan masalah, atau membuat kesimpulan, matematika lebih pada suatu alat untuk mengkomunikasikan berbagai gagasan secara benar, tepat, dan secara singkat, dan (2) matematika dan pembelajaran matematika adalah aktivitas sosial dalam pengajaran matematika, interaksi seperti komunikasi antara guru dan siswa dengan diri mereka sendiri, hal itu penting untuk meningkatkan potensi matematika siswa. Selanjutnya, Baroody juga mengemukakan bahwa, "Improving student's ability to communicate mathematics is one of the major goals of the mathematics reform movement". Maksud dari kalimat tersebut yakni, tujuan penting dalam matematika adalah meningkatkan kemampuan komunikasi matematis siswa.

Komunikasi matematis adalah cara bagi siswa untuk mengkomunikasikan ide-ide pemecahan masalah, strategi maupun solusi matematika baik secara tertulis maupun lisan. Sedangkan, kemampuan komunikasi matematis dalam memecahkan masalah [7] dapat dilihat ketika siswa dapat menggunakan bahasa matematika untuk menyatakan ide matematika dengan tepat. Kemampuan komunikasi diperlukan untuk menuangkan ide-ide matematis sehingga membantu siswa dalam menyelesaikan masalahmasalah matematis.

Beberapa hasil penelitian tentang komunikasi matematis diantaranya yang dilakukan oleh Larsson pada [5] meneliti tentang percobaan untuk mengembangkan kemampuan komunikasi matematika siswa di bidang matematika. Penelitian ini memfokuskan pada kemampuan representasi, diskusi, dan menulis matematika. Pembelajaran dilakukan mengarah pada partisipasi siswa saat presentasi, diskusi, dan penulisan tentang penyelesaian masalah matematika. Hasil penelitian ini menunjukkan bahwa peningkatan kemampuan komunikasi matematika siswa terlihat pada proses pembelajaran yang melibatkan diskusi. Bergeson dalam penelitian Satriawati [9] mengemukakan bahwa siswa sulit mengkomunikasikan informasi visual terutama dalam mengkomunikasikan sebuah lingkungan tiga dimensi (misalnya, sebuah bangunan terbuat dari balok kecil) melalui alat dua dimensi (misalnya, kertas dan pensil) atau sebaliknya. Selanjutnya penelitian mengenai kemampuan komunikasi matematis dilakukan oleh Kongthip et al [4] dengan tujuan untuk mengeksplorasi kemampuan komunikasi matematis melalui gerak tubuh (gestures) pada siswa kelas 5 dalam suatu pembelajaran matematika yang menggunakan Lesson Study and Open Approach Context. Penelitian Kongtip et al ini menemukan bahwa anak sekolah dasar, khususnya pada siswa kelas 5 biasa menggunakan gerakan-gerakan dalam menjelaskan ide matematika sebagai salah satu bentuk komunikasi mereka. Hal ini menunjukkan bahwa masih banyak siswa yang mengalami kesulitan dalam berkomunikasi secara matematis, sehingga beberapa gerakan tubuh (gestures) menjadi jembatan untuk menunjukkan sejauh mana penalaran yang mereka miliki tentang konsep matematika. Berdasarkan penelitian-penelitian mengenai kemampuan komunikasi matematis siswa, penulis tertarik untuk menganalisis 
kemampuan komunikasi matematis siswa SMP dalam memecahkan masalah matematika.

\section{Pembahasan}

Penelitian ini merupakan penelitian kualitatif berjenis studi kasus, yaitu menganalisis kemampuan komunikasi matematis siswa yang ditinjau gaya kognitif reflective-impulsive. Penelitian ini dilakukan di SMP Negeri 1 Sumberrejo yang dimulai pada bulan Januari sampai Juni 2016 mulai tahap persiapan hingga penulisan laporan penelitian.

Penentuan subjek penelitian dilakukan dengan menggunakan sampel bertujuan (purposive sample). Menurut Moleong [6], sampel bertujuan dipilih bukan untuk memusatkan diri pada adanya perbedaanperbedaan yang nantinya dikembangkan ke dalam generalisasi, tetapi untuk merinci kekhususan yang ada ke dalam ramuan konteks yang unik. Selain itu untuk menggali informasi yang akan menjadi dasar dari rancangan dan teori yang muncul. Subjek penelitian ini diawali dengan memberikan tes penempatan pada 27 siswa kelas VII SMP Negeri 1 Sumberrejo tahun ajaran 2015/2016 untuk mengkategorikan siswa ke dalam gaya kognitif reflective-impulsive. Hasil dari tes penempatan menunjukkan 15 anak memiliki gaya kognitif reflective dan 12 anak memiliki gaya kognitif impulsive.

Data dalam penelitian ini berupa kemampuan komunikasi matematis dalam memecahkan masalah matematika yang diperoleh dari hasil tes tertulis dan transkrip wawancara yang dilakukan sebanyak dua kali tes tertulis dan wawancara. Hasil transkrip tersebut berupa percakapan peneliti dan subjek yang selanjutnya direduksi untuk memperoleh data terkait kemampuan komunikasi matematis. Selanjutnya, dilakukan pengkategorian terhadap data hasil reduksi berdasarkan aspek komunikasi matematis yang terdiri dari tiga aspek, yaitu menulis matematis, menggambar secara matematis, dan ekspresi matematis. Data yang sudah dikategorikan tersebut disesuaikan dengan indikator tingkat komunikasi matematis yakni tingkat 0 sampai tingkat 4 . Validitas data yang digunakan dalam penelitian ini adalah triangulasi waktu. Pengujian kredibilitas data dengan triangulasi waktu dilakukan dengan cara melakukan pengecekan data melalui wawancara dalam waktu atau situasi yang berbeda. Pada penelitian ini, proses triangulasi dilakukan dengan menganalisis data yang diperoleh dari data pertama kemudian dibandingkan dengan data kedua. Pada data pertama subjek diberi tes tertulis kemudian dilakukan wawancara untuk dilakukan verifikasi terhadap jawaban soal tes tertulis sehingga diperoleh kepastian data. Setelah itu, diambil data yang kedua dengan waktu yang berbeda berdasarkan prosedur yang sama. Data dikatakan valid jika data pertama memberikan kecenderungan hasil yang sama jika dibandingkan dengan data yang kedua. Namun, jika data tersebut tidak valid maka data tersebut dibuang. Setelah dilakukan pengambilan data pada sumber pertama maka dilakukan pengambilan data dari sumber kedua dan begitu seterusnya sampai peneliti mendapatkan hasil yang benar-benar valid mengenai kemampuan dan tingkat komunikasi matematis siswa pada masing-masing gender dan gaya kognitif yang berbeda.

Berdasarkan hasil tes dan wawancara I serta tes dan wawancara II yang dilakukan oleh sembilan subjek dengan masing-masing empat siswa dengan gaya kognitif reflective, dan empat siswa gaya kognitif impulsive, maka terdapat perbedaan kemampuan komunikasi matematis pada masing-masing kategori gaya kognitif.

Kemampuan komunikasi matematis untuk siswa dengan gaya kognitif reflective meliputi: (1) kemampuan menulis; subjek dapat memahami masalah secara keseluruhan dan menentukan permasalahan yang ingin dijawab, dan siswa dapat menuliskan secara matematis informasi-informasi penting dari soal, (2) kemampuan menggambar secara matematis; subjek dapat menyatakan permasalahan matematika ke dalam gambar tetapi kurang lengkap dan terdapat sedikit kesalahan, (3) kemampuan ekspresi matematis; subjek dapat membuat persamaan matematika 
terkait permasalahan yang diberikan, siswa dapat menyatakan langkah pemecahan masalah tetapi kurang terstruktur, dan siswa dapat melakukan perhitungan untuk memperoleh solusi tetapi masih terdapat sedikit kesalahan.

Kemampuan komunikasi matematis untuk siswa dengan gaya kognitif impulsive meliputi: : (1) kemampuan menulis; subjek dapat memahami masalah secara keseluruhan dan menentukan permasalahan yang ingin dijawab, dan subjek dapat menuliskan secara matematis informasi-informasi penting dari soal, (2) kemampuan menggambar secara matematis; subjek dapat menyatakan permasalahan matematika ke dalam gambar tetapi kurang lengkap dan masih terdapat banyak kesalahan, (3) kemampuan ekspresi matematis: subjek dapat membuat persamaan matematika terkait permasalahan yang diberikan, subjek dapat menyatakan langkah pemecahan masalah, subjek dapat melakukan perhitungan untuk memperoleh solusi tetapi masih terdapat banyak kesalahan.

Berdasarkan hasil penelitian yang sudah dijelaskan, kemampuan komunikasi matematis tertinggi yang dicapai siswa adalah pada aspek menulis matematis, yakni pada level 4 yang di capai oleh siswa dengan gaya kognitif reflective. Hal ini sesuai dengan salah satu standar komunikasi matematis siswa pada tingkat 6-8 yang dirumuskan oleh NCTM [7] yakni, pada tingkat 6-8 siswa seharusnya sudah mampu mengkomunikasikan pemikiran matematis mereka secara koheren dan jelas kepadar rekan-rekan, guru, dan lain-lain, baik secara tulisan maupun lisan. Sedangkan untuk aspek menggambar secara matematis dan ekspresi matematis belum dapat dicapai secara maksimal oleh siswa. Siswa belum dapat mencapai level 4, melainkan hanya sampai pada level 3. Hal ini bertentangan dengan beberapa standar komunikasi matematis pada tingkat 6-8 yang lain, yang juga dirumuskan oleh NCTM [7] yakni, pada tingkat 6-8 siswa seharusnya sudah mampu menggunakan bahasa matematika untuk mengekspresikan ide-ide matematika secara tepat. Selain itu, kemampuan komunikasi matematis yang dikembangkan di tiap-tiap tingkat kelas memiliki karakteristik yang berbeda. Pada tingkat-tingkat kelas 5-8 seharusnya siswa mampu memodelkan situasi-situasi menggunakan metode konkret, gambar, grafik dan aljabar.

Berdasarkan penelitian ini, kelengkapan dan keakuratan komunikasi matematis siswa kelas VII C SMP Negeri 1 Sumberrejo juga lebih banyak dicapai oleh dengan gaya kognitif reflective. Hasil ini didukung oleh penelitian Philip [8] mengatakan bahwa, anak reflective mempertimbangkan banyak alternatif sebelum merespon sehingga tinggi kemungkinan bahwa respon yang diberikan adalah benar, sedangkan anak impulsive akan mengambil keputusan dengan cepat tanpa memikirkannya secara mendalam sehingga tinggi kemungkinan bahwa respon yang diberikan tidak tepat. Hal ini juga didukung oleh pernyataan Desmita [1] bahwa siswa dengan gaya reflektive cenderung menggunakan lebih banyak waktu untuk merespons dan merenungkan akurasi jawab.

\section{Penutup}

Berdasarkan hasil penelitian dan pembahasan mengenai kemampuan komunikasi matematis tertulis berdasarkan gaya kognitif reflective-impulsive kelas VII SMP Negeri 1 Sumberrejo diperoleh kesimpulan sebagai berikut. (1) Siswa dengan gaya kognitif reflective memiliki kemampuan komunikasi matematis yakni, menulis matematis; siswa dapat memahami masalah secara keseluruhan dan menentukan permasalahan yang ingin dijawab, siswa dapat menuliskan secara matematis informasiinformasi penting dari soal dan kemampuan menulis matematis siswa berada pada level 4 . Menggambar secara matematis; siswa dapat menyatakan permasalahan matematika ke dalam gambar tetapi kurang lengkap dan terdapat sedikit kesalahan, sehingga kemampuan siswa menggambar secara matematis berada pada level 3. Ekspresi matematis; siswa dapat membuat persamaan matematika terkait permasalahan yang diberikan; siswa dapat menyatakan langkah 
pemecahan masalah tetapi kurang terstruktur; siswa dapat melakukan perhitungan untuk memperoleh solusi tetapi masih terdapat sedikit kesalahan, sehingga kemampuan ekspresi matematis siswa berada pada level 3 . (2) Siswa dengan gaya kognitif impulsive memiliki kemampuan komunikasi matematis yakni, menulis matematis; siswa dapat memahami masalah secara keseluruhan dan menentukan permasalahan yang ingin dijawab; siswa dapat menuliskan secara matematis informasi-informasi penting dari soal dan kemampuan menulis matematis siswa berada pada level 4. Menggambar secara matematis; siswa dapat menyatakan permasalahan matematika ke dalam gambar tetapi kurang lengkap dan masih terdapat kesalahan sehingga kemampuan siswa menggambar secara matematis berada pada level 2. Ekspresi matematis; siswa dapat membuat persamaan matematika terkait permasalahan yang diberikan; siswa dapat menyatakan langkah pemecahan masalah; siswa dapat melakukan perhitungan untuk memperoleh solusi tetapi masih terdapat banyak kesalahan sehingga kemampuan ekspresi matematis siswa berada pada level 2.

Berdasarkan hal tersebut, peneliti memberikan beberapa saran agar guru sebaiknya memperhatikan tugas dan penyampaian materi garis dan sudut tentang hubungan, garis, sudut, serta menentukan ukurannya. Hal ini bertujuan agar siswa memahami dengan benar kedudukan sudutsudut yang terjadi jika dua garis dipotong garis lain. Dalam menyusun tugas sekolah atau rumah, guru sebaiknya lebih menekankan kemampuan komunikasi matematis siswa, seperti soal-soal yang menuntut kemampuan siswa dalam menyatakan permasalahan matematika ke dalam gambar. Guru juga sebaiknya lebih banyak memberikan soal pemecahan masalah non rutin. Hal ini bertujuan agar siswa semakin terbiasa menghadapi masalah matematika, selain itu langkah-langkah pemecahan masalah dapat membuat siswa lebih runtut dalam memecahkan masalah matematika.

\section{Referensi}

[1] Desmita. Psikologi Perkembangan Peserta Didik. Bandung: PT. Remaja Rosdakarya (2011).

[2] Depdiknas. Permendiknas No 22 Tahun 2006 Tentang Standar Isi. Jakarta: Depdinkas (2006).

[3] Kadir and Parman. Mathematical Communication Skills of Junior Secondary School Student in Coastal Area. Jurnal Teknologi, 63 (2), (2013) 7783.

[4] Kongthip, Y, Inprasitha, M, Pattanajak, A, \& Inprasitha, N. Mathematical Communication by 5th Grade Student 'e $^{\text {s }}$ Gestures in Lesson Study and Open Approach Context. Psychology, 3 (8), (2012) 632-637.

[5] Larsson, J.A. Communication of Mathematics as a Tool to Improve Students' General Communicative Skill. Proccedings of the 3rd International CDIO Conference, MIT, Cambridge, Massachusetts, USA, June (2007) 11-14.

[6] Moleong, L.J. Metode Peneltian Kualitatif. Bandung : PT Remaja Rosdakarya. (2013).

[7] NCTM. (2000). Curriculum and Evaluation Standard for School Mathematics. Reston: National Council of Teacher of Mathematics. (2013).

[8] Philip, F. (1977). The Effect of Verbal and Material Rewards and Punisher on The Performance of Impulsive and Reflective Children. Child study journal 7(2) (2013) 71-78.

[9] Satriawati, G. Pembelajaran dengan Pendekatan Open Ended Untuk Meningkatkan Pemahaman Kominikasi Matematis Siswa SMP. Jurnal Algoritma CeMED Jurusan Pendidikan Matematika UIN Jakarta, 1 (1) (2006) 107-115. 
http://journal.unugiri.ac.id/index.php?journal=JaMES 